\title{
Mulberry Protection through Flowering-Stage Essential Oil of Artemisia annua against the Lesser Mulberry Pyralid, Glyphodes pyloalis Walker
}

\author{
Marziyeh Oftadeh ${ }^{1}$, Jalal Jalali Sendi ${ }^{1,2, * \mathbb{D}}$, Asgar Ebadollahi ${ }^{3, *(\mathbb{D},}$, William N. Setzer ${ }^{4,5}$ and \\ Patcharin Krutmuang 6,7,*这
}

1 Department of Plant Protection, Faculty of Agricultural Sciences, University of Guilan, Rasht 416351314, Iran; marziye.oftade@gmail.com

2 Department of Silk Research, Faculty of Agricultural Sciences, University of Guilan, Rasht 416351314, Iran

3 Department of Plant Sciences, Moghan College of Agriculture and Natural Resources, University of Mohaghegh Ardabili, Ardabil 5697194781, Iran

4 Department of Chemistry, University of Alabama in Huntsville, Huntsville, AL 35899, USA; wsetzer@chemistry.uah.edu

5 Aromatic Plant Research Center, 230 N 1200 E, Suite 100, Lehi, UT 84043, USA

6 Department of Entomology and Plant Pathology, Faculty of Agriculture, Chiang Mai University, Chiang Mai 50200, Thailand

7 Innovative Agriculture Research Center, Faculty of Agriculture, Chiang Mai University, Chiang Mai 50200, Thailand

check for

updates

Citation: Oftadeh, M.; Sendi, J.J.; Ebadollahi, A.; Setzer, W.N.;

Krutmuang, P. Mulberry Protection through Flowering-Stage Essential Oil of Artemisia annua against the Lesser Mulberry Pyralid, Glyphodes pyloalis Walker. Foods 2021, 10, 210. https://doi.org/10.3390/foods 10020210

Academic Editors: Marie-Laure Fauconnier, Haïssam Jijakli and Caroline De Clerck

Received: 26 November 2020

Accepted: 19 January 2021

Published: 20 January 202

Publisher's Note: MDPI stays neutral with regard to jurisdictional claims in published maps and institutional affiliations.

Copyright: (c) 2021 by the authors. Licensee MDPI, Basel, Switzerland. This article is an open access article distributed under the terms and conditions of the Creative Commons Attribution (CC BY) license (https:/ / creativecommons.org/licenses/by/ $4.0 /)$.
* Correspondence: jjalali@guilan.ac.ir (J.J.S.); ebadollahi@uma.ac.ir (A.E.); patcharink26@gmail.com (P.K.)

Abstract: In the present study, the toxicity and physiological disorders of the essential oil isolated from Artemisia annua flowers were assessed against one of the main insect pests of mulberry, Glyphodes pyloalis Walker, announcing one of the safe and effective alternatives to synthetic pesticides. The $\mathrm{LC}_{50}$ (lethal concentration to kill $50 \%$ of tested insects) values of the oral and fumigant bioassays of $A$. annua essential oil were $1.204 \% \mathrm{~W} / \mathrm{V}$ and $3.343 \mu \mathrm{L} / \mathrm{L}$ air, respectively. The $A$. annua essential oil, rich in camphor, artemisia ketone, $\beta$-selinene, pinocarvone, 1,8 -cineole, and $\alpha$-pinene, caused a significant reduction in digestive and detoxifying enzyme activity of G. pyloalis larvae. The contents of protein, glucose, and triglyceride were also reduced in the treated larvae by oral and fumigant treatments. The immune system in treated larvae was weakened after both oral and fumigation applications compared to the control groups. Histological studies on the midgut and ovaries showed that $A$. annua essential oil caused an obvious change in the distribution of the principal cells of tissues and reduction in yolk spheres in oocytes. Therefore, it is suggested that the essential oil from A. annua flowers, with wide-range bio-effects on G. pyloalis, be used as an available, safe, effective insecticide in the protection of mulberry.

Keywords: essential oil; sweet wormwood; mulberry pyralid; mulberry; immunity; reproductive system; digestive system

\section{Introduction}

The mulberry (Morus sp. (Rosales: Moraceae)) leaves are used for rearing silkworm (Bombyx mori L. (Lepidoptera: Bombycidae)). The importance of lesser mulberry pyralid Glyphodes pyloalis Walker (Lepidoptera: Pyralidae)) is from the larvae damaging mulberry leaves and the transmission of plant pathogenic agents [1]. The extensive use of synthetic chemical pesticides has led to many concerns about the safety of humans, beneficial insects, and the environment $[2,3]$. Thus, management of insect pest through eco-friendly and biodegradable agents is critical in sericulture.

The essential oils obtained from several parts of plants, including leaves, flowers, fruits, twigs, bark, seeds, wood, rhizomes, and roots, are made as secondary metabolites in 
the plant and possess diverse chemical compositions [4]. The effectiveness of essential oils as a more sustainable pest management tool has been noted previously [5-7]. It can easily be inferred from their biodegradable nature and safety compared to many of the synthetic insecticides. Since they have multiple target sites in insects, their application is less likely to result in resistance in comparison with synthetic insecticides [8]. It was indicated that plantderived essential oils may have several effects, including ovicidal, ovipositional deterrents, feeding deterrents, growth retardants, and inhibition in detoxification enzymes [9-11].

The annual wormwood, Artemisia annua L. (Asterales: Asteraceae), native to temperate Asia, has been naturalized in many countries [12]. The $A$. annua has traditionally been used to treat certain diseases of humans, including asthma, fever, malaria, skin diseases, jaundice, circulatory disorders, and hemorrhoids [13]. Although our previous findings of the essential oil or extracts in the vegetative stage of $A$. annua showed the high potential of this medicinal plant species on insect pest control [14-18], the insecticidal effects of its floral essential oil were evaluated against G. pyloalis in the present study.

The evaluation of lethal (acute) and sublethal (chronic) effects of essential oil extracted from A. annua flowers on G. pyloalis was the main objective of the current study, recommending a biorational and available agent as a possible replacement for synthetic insecticides. Fumigant toxicity is considered to be a non-residual treatment in which no residue will commonly remain for future contaminants. In oral toxicity, the pest is eliminated by swallowing infested food, and it is a suitable method for controlling leaf-eating pests. Therefore, fumigant and oral toxicity and the effect on some key enzymes and biochemical compounds, immunology, digestive system in the larvae, and the ovary of emerged adults of insects, along with the chemical analysis of the essential oil, were evaluated.

\section{Materials and Methods}

\subsection{Insects' Rearing}

The larvae of G. pyloalis were handpicked from a mulberry orchard within the University of Guilan campus, Rasht $\left(37.2682^{\circ} \mathrm{N}, 49.5891^{\circ} \mathrm{E}\right)$, Iran. The larvae were maintained on fresh leaves of 'Shin Ichinoise' mulberry variety in disposable transparent containers (high-density polyethylene plastic containers, $10 \times 20 \times 5 \mathrm{~cm}$ ) in a rearing room set at $25 \pm 1{ }^{\circ} \mathrm{C}, 75 \pm 5 \% \mathrm{RH}$ (Relative Humidity), and 16:8 L:D (Light:Dark). The emerging adults were reserved in glass jars $(18 \times 7 \times 5 \mathrm{~cm})$, in which fresh leaves were positioned for egg laying, and $10 \%$ honey-soaked cotton wool was provided for feeding.

\subsection{Essential Oil}

\subsubsection{Extraction of the Essential Oil}

The mature and immature flowers of A. annua (autumn 2018) were collected on the University of Guilan campus. Samples were dried on a table out of direct sunlight for about a week until sufficiently dry to form a powder when ground. The dried flowers were made into a fine powder by a grinder (354, Moulinex, Normandy, France), and a solution was made with distilled water $(50 \mathrm{~g} / 750 \mathrm{~mL})$. The solution was let to stand in the dark at laboratory room temperature for $24 \mathrm{~h}$ to maximum essential oil extraction. The mixture was distilled to extract the essential oil using a Clevenger apparatus (J3230, Sina glass, Tehran, Iran). The distillation process was run for two hours and the obtained essential oil was dried over anhydrous sodium sulfate. The obtained essential oil was stored in dark glass vials at $4{ }^{\circ} \mathrm{C}$ in a refrigerator until used.

\subsubsection{Determination of Essential Oil Composition}

The essential oil was analyzed through gas chromatography (Agilent Technologies 7890B) coupled with a mass spectrometer (Agilent Technologies 5977A), which was armed with an HP-5MS ((5\%-phenyl)-methylpolysiloxane) capillary column with a 30-m length, $0.25-\mathrm{mm}$ width, and an internal thickness of $0.25 \mu \mathrm{m}$. Helium gas at a $1 \mathrm{~mL} / \mathrm{min}$ flow rate was used, while the column temperature started from 50 and reached to $280{ }^{\circ} \mathrm{C}$ at a rate of $5{ }^{\circ} \mathrm{C} / \mathrm{min}$. A $10 \%$ A. annua essential oil solution in methanol $(v / v)$ was prepared, and 
$1 \mu \mathrm{L}$ of solution was injected. Spectra were obtained in the electron impact mode with $70 \mathrm{eV}$ of ionization energy. The scan range was between 30-600 $\mathrm{m} / \mathrm{z}$. The identification of components was performed by comparing mass spectral fragmentation patterns and retention indices with those described in the databases $[19,20]$.

\subsection{Insecticidal Activity}

\subsubsection{Oral Toxicity}

Initial tests were conducted to assist in selecting the appropriate range of concentrations. Bioassays were carried out on $4^{\text {th }}$ instar larvae, which were deprived of nutrition for $4 \mathrm{~h}$ before the onset of experiments. The essential oil concentrations of $0.5,0.7,1,1.4$ and $2 \%$ $(W / V)$ in acetone as solvent (Merck, Darmstadt, Germany) were selected. For bioassays, mulberry leaf disks ( $8 \mathrm{~cm}$ in diameter) were immersed in desired concentrations for $10 \mathrm{~s}$ and then air-dried at room temperature for $30 \mathrm{~min}$. Ten 4th instar G. pyloalis were placed on each disk. The mortality was documented after $24 \mathrm{~h}$. Control groups were placed on disks treated with acetone. The control and treated groups were replicated four times.

\subsubsection{Fumigant Activity}

In order to carry out fumigation bioassays, two transparent polyethylene plastic containers (Pharman polymer company, Rasht, Iran) were used. A 250-mL container was used to place 104 th instar larvae of mulberry pyralid. They were provided with fresh mulberry leaf disks, and the container top was covered with fine cotton fabric for aeration. The container was then placed inside a $1000-\mathrm{mL}$ container. The desired amount of pure essential oil was poured onto filter papers (Whatman No. 1) cut to $2 \mathrm{~cm}$ in diameter using a micro applicator. It was then placed in the corner of the larger container, and its lid tightly sealed using Parafilm. The concentrations of 2, 3, 4, 5 and $6 \mu \mathrm{L} / \mathrm{L}$ air were used for this bioassay based on the initial tests. The controls were treated in the same way without any treatments of the filter papers. All tests were replicated four times.

\subsection{Digestive Enzymes' Assays}

In order to evaluate digestive enzymes activity, the larvae that were treated with $\mathrm{LC}_{50}$, $\mathrm{LC}_{30}$, and $\mathrm{LC}_{10}$ (Lethal Concentration to kill 50,30 , and $10 \%$ of insects, respectively) dosages of essential oil obtained from oral and fumigant bioassays and the controls were dissected in ringer's solution ( $9 \% v / v \mathrm{NaCl}$ and isotonic) $24 \mathrm{~h}$ after treatment and their digestive systems (only midguts) were dissected out. Five midguts for each treatment and control were first homogenized in $500 \mu \mathrm{L}$ of universal buffer ( $50 \mathrm{mM}$ sodium phosphate-borate at pH 7.1) in a tissue homogenizer (DWK885300-0001-1EA, Merk, Darmstadt, Germany). The supernatant was then kept at $-20{ }^{\circ} \mathrm{C}$ until analyzed.

\subsubsection{The $\alpha$-Amylase Activity}

The reagent dinitrosalicylic acid (DNS, Sigma, St. Louis, MI, USA) in 1\% soluble starch was used to estimate $\alpha$-amylase activity according to the method of Bernfeld (1955) [21]. Briefly, $20 \mu \mathrm{L}$ of the enzyme was poured into $40 \mu \mathrm{L}$ of soluble starch and $100 \mu \mathrm{L}$ of universal buffer (pH 7). The mixture was incubated for $30 \mathrm{~min}$ at $35^{\circ} \mathrm{C}$, and DNS $(100 \mu \mathrm{L})$ was then added to stop the reaction. The absorbance was read at $540 \mathrm{~nm}$ in an ELISA reader (Awareness, Temecula, CA, USA).

\subsubsection{Protease Assay}

The protease activity was assessed by addition of $200 \mu \mathrm{L}$ of casein solution casein (1\%) to $100 \mu \mathrm{L}$ of enzyme and $100 \mu \mathrm{L}$ universal buffer ( $\mathrm{pH} 7$ ). Then, the obtained mixture was incubated at $37^{\circ} \mathrm{C}$ for $60 \mathrm{~min}$ [22]. The mixture was centrifuged at $8000 \times g$ within $15 \mathrm{~min}$ and the absorbance was read at $440 \mathrm{~nm}$. 


\subsubsection{Lipase Estimation}

The method of Tsujita et al. (1989) [23] was adopted to estimate lipase. Concisely, $10 \mu \mathrm{L}$ enzyme, $18 \mu \mathrm{L}$ p-nitrophenyl butyrate $(50 \mathrm{mM})$, and $172 \mu \mathrm{L}$ universal buffer $(\mathrm{pH} 7)$ were mixed and incubated at $37^{\circ} \mathrm{C}$ for $30 \mathrm{~min}$. The absorbance was recorded at $405 \mathrm{~nm}$ in the ELISA reader.

\subsubsection{The $\alpha$ - and $\beta$-Glucosidase Estimation}

Here, we used Triton X-100 in order to hydrolyze glucosidases ( $\alpha$ - and $\beta$-) for $20 \mathrm{~h}$ at $40{ }^{\circ} \mathrm{C}$ in a ratio of $10 \mathrm{mg}$ of Triton $\mathrm{X}-100 / \mathrm{mg}$ protein. Then, we incubated $75 \mathrm{~mL}$-nitrophenyl$\alpha$-D-glucopyranoside ( $\mathrm{pNaG}, 5 \mathrm{mM}$ ), p-nitrophenyl- $\beta$-D-glucopyranoside ( $\mathrm{pNbG}, 5 \mathrm{mM}), 125$ $\mathrm{mL}$ universal buffer (made of $2 \% \mathrm{Mol}$ MES (2-(N-morpholino)ethanesulfonic acid), glycine, and succinate, $100 \mathrm{mM}, \mathrm{pH} 5.0$ ), and $50 \mathrm{~mL}$ enzyme solution. In order to stop the reaction, $2 \mathrm{~mL}$ of sodium carbonate (1 M) was used and the absorbance was read at $450 \mathrm{~nm}$ [24].

\subsection{Detoxifying Enzymes' Assays}

Quantitative analyses of biochemical constituents were carried out on insects remaining after treatments with $\mathrm{LC}_{10}, \mathrm{LC}_{30}$, and $\mathrm{LC}_{50}$ and controls. To quantify the whole body protein, the method of Bradford (1976) [25], using the kit (GDA01A, Biochem Co., Tehran, Iran), was incorporated, while glucose and triglyceride were measured by Siegert (1987) [26] method and the triglyceride diagnostic kit, respectively (Pars Azmoon Co., Tehran, Iran). Key enzymes including esterase (general esterases with $\alpha$ - and $\beta$-naphthyl acetate substrates), glutathione S-transferase (GST), and phenol oxidase (PO) were assessed by the method described by van Asperen (1962) [27], Habing et al. (1974) [28], and Parkinson and Weaver (1999) [29], respectively.

\subsection{Hematological Study}

The amount of various circulating blood cells in $\mathrm{mm}^{-3}$ of larval lesser mulberry pyralid treated with sublethal doses of $A$. annua oil and in controls were assessed. The hemolymph was drawn from one of the larval prolegs, cutting by a fine scissor, using a capillary glass tube $(10 \mu \mathrm{L}$ for each treatment). Then, the blood was diluted five times with a solution of anticoagulant (0.017 M EDTA, $0.186 \mathrm{M} \mathrm{NaCl}, 0.098 \mathrm{M} \mathrm{NaOH}$, and 0.041 $\mathrm{M}$ citric acid at $\mathrm{pH}$ 4.5). An improved Neubauer hemocytometer (mlabs, HBG, Giessen, Germany) [30] was used to assess the total cells using the formula of Jones (1962) [31]. A drop of hemolymph was collected from cut proleg of treated and control larvae. A smear was formed and stained with diluted Giemsa (Merck, Darmstadt, Germany) in distilled water (1:9) for $25 \mathrm{~min}$, then just dipped in a saturated solution of lithium carbonate, and, finally, washed with distilled water. Permanent slides were prepared in Canada balsam (Merck Darmstadt, Germany). The percentage profile of different cells was done after identification and counting of 200 cells per slide [32].

\section{Immunity Responses}

Initially the treated or control larvae were made immobile by keeping them on ice cubes for five minutes. Then, they were surface sterilized and injected with $1 \times 10^{4}$ spores $/ \mathrm{mL}$ in $0.01 \%$ Tween- 80 of Beauveria bassiana (IRAN403C isolate) or latex beads (1:10 dilution for each suspension and Tween-80, respectively) on the second abdominal sternum using a $10-\mu \mathrm{L}$ Hamilton syringe. The treated larvae were then transferred to glass jars and were given fresh leaves of mulberry. The control larvae were injected with $1 \mu \mathrm{L}$ of distilled water comprising $0.01 \%$ of Tween- 80 only. The hemolymph was collected $24 \mathrm{~h}$ post-injection from each larva, and the number of nodules formed was scored in a hemocytometer [33]. The counting was repeated four times for each group.

\subsection{Histological Studies of Larvae Midgut and Adults' Ovary}

The larvae midguts were separated from the whole dissected gut in insect ringer and were immediately fixed in aqueous Buine solution for $24 \mathrm{~h} \mathrm{[10].} \mathrm{Also,} \mathrm{the} \mathrm{ovary} \mathrm{of}$ 
adults ( 2 days old), emerging from either treated or control larvae, were separated and fixed. The tissues were processed for embedding in paraffin after being dehydrated in grades of ethanol alcohol and also cleaned by xylene. The fixed tissues were then cut by $5-\mu \mathrm{M}$ thickness through a rotary microtome (Model 2030; Leica, Wetzlar, Germany). The hematoxylin and eosin were used for staining and then permanent slides were thus prepared, observed, and photographed under a light microscope (M1000 light microscope; Leica, Wetzlar, Germany) armed with an EOS 600D digital camera (Canon, Tokyo, Japan).

\subsection{Statistical Analysis}

LC values were determined using the Polo-Plus software (2002) [34]. All the data were analyzed by ANOVA (SAS Institute, Cary, Cary, NC, USA, 1997) [35], and the comparison of means was performed using Tukey's multiple comparison test $(p<0.05)$.

\section{Results}

\subsection{A. annua Essential Oil Analysis}

The chemical composition of extracted A. annua essential oil is presented in Table 1. We identified 55 compounds in flowers of this plant, which represent $93.0 \%$ of the total composition. Camphor (13.1\%), artemisia ketone (11.8\%), $\beta$-selinene (10.7\%), pinocarvone (7.4\%), 1,8-cineole (6.8\%), and $\alpha$-pinene (5.9\%) were considered as the major compounds detected, all of which are terpenes. However, other groups such as ester and phenylpropene were also recognized (Table 1).

Table 1. Chemical composition of the of Artemisia annua floral essential oil.

\begin{tabular}{|c|c|c|c|c|c|c|c|}
\hline $\mathrm{RI}_{\text {calc }}$ & $\mathrm{RI}_{\mathrm{db}}$ & Compound & $\%$ & $\mathrm{RI}_{\text {calc }}$ & $R I_{d b}$ & Compound & $\%$ \\
\hline 923 & 926 & Tricyclene $\mathrm{MH}$ & 0.2 & 1258 & 1259 & Lepalone $\mathrm{OM}$ & 0.1 \\
\hline 938 & 939 & $\alpha$-Pinene $\mathrm{MH}$ & 5.9 & 1281 & 1278 & Lepalol OM & 0.3 \\
\hline 978 & 975 & Sabinene ${ }^{\mathrm{MH}}$ & 0.3 & 1299 & 1290 & p-Cymen-7-ol OM & 0.2 \\
\hline 982 & 979 & $\beta$-Pinene ${ }^{\mathrm{MH}}$ & 0.1 & 1337 & 1327 & $p$-Mentha-1,4-dien-7-ol OM & 0.2 \\
\hline 992 & 990 & Myrcene $\mathrm{MH}$ & 0.4 & 1361 & 1359 & Eugenol ${ }^{\mathrm{PP}}$ & 0.6 \\
\hline 1013 & 999 & Yomogi alcohol OM & 1.2 & 1374 & 1376 & $\alpha$-Copaene ${ }^{\mathrm{SH}}$ & 1.0 \\
\hline 1021 & 1024 & p-Cymene $\mathrm{MH}$ & 0.8 & 1391 & 1392 & Benzyl 2-methylbutanoate ${ }^{\mathrm{E}}$ & 0.3 \\
\hline 1026 & 1026 & $o$-Cymene $\mathrm{MH}$ & 0.8 & 1402 & 1392 & (Z)-Jasmone OC & 0.1 \\
\hline 1030 & 1031 & 1,8-Cineole $\mathrm{OM}$ & 6.8 & 1420 & 1419 & (E)- $\beta$-Caryophyllene ${ }^{\mathrm{SH}}$ & 3.1 \\
\hline 1061 & 1062 & Artemisia ketone $\mathrm{OM}$ & 11.8 & 1426 & 1432 & $\beta$-Copaene $\mathrm{SH}$ & 0.2 \\
\hline 1074 & 1070 & cis-Sabinene hydrate $\mathrm{OM}$ & 0.5 & 1448 & 1454 & $\alpha$-Humulene ${ }^{\mathrm{SH}}$ & 0.3 \\
\hline 1082 & 1083 & Artemisia alcohol $\mathrm{OM}$ & 1.4 & 1455 & 1456 & (E)- $\beta$-Farnesene ${ }^{\mathrm{SH}}$ & 1.0 \\
\hline 1104 & 1114 & $\begin{array}{l}\text { 3-Methyl-3-butenyl } \\
\text { 3-methylbutanoate E }\end{array}$ & 0.8 & 1471 & 1477 & $\beta$-Chamigrene ${ }^{\mathrm{SH}}$ & 0.2 \\
\hline 1119 & 1126 & $\alpha$-Campholenal $\mathrm{OM}$ & 0.7 & 1478 & 1485 & Germacrene D $\mathrm{SH}$ & 0.7 \\
\hline 1131 & 1144 & trans-Pinocarveol OM & 0.4 & 1489 & 1490 & $\beta$-Selinene ${ }^{\mathrm{SH}}$ & 10.7 \\
\hline 1144 & 1146 & Camphor OM & 13.1 & 1510 & 1516 & Isobornyl isovalerate $\mathrm{OM}$ & 0.1 \\
\hline 1161 & 1164 & Pinocarvone OM & 7.4 & 1517 & 1523 & $\delta$-Cadinene $\mathrm{SH}$ & 0.1 \\
\hline 1169 & 1169 & Borneol OM & 1.5 & 1547 & 1555 & iso-Caryophyllene oxide OS & 0.3 \\
\hline 1179 & 1177 & Terpinene-4-ol OM & 2.2 & 1585 & 1583 & Caryophyllene oxide OS & 5.4 \\
\hline 1192 & 1188 & $\alpha$-Terpineol OM & 0.9 & 1588 & 1590 & $\beta$-Copaene- $4 \alpha$-ol OS & 0.2 \\
\hline 1199 & 1195 & Myrtenol ${ }^{\mathrm{OM}}$ & 2.6 & 1594 & 1594 & Salvial-4(14)-en-1-one OS & 0.2 \\
\hline 1211 & 1205 & Verbenone $\mathrm{OM}$ & 0.3 & 1643 & 1640 & Caryophylla-4(12),8(13)-dien-5 $\beta$-ol OS & 1.3 \\
\hline 1219 & 1216 & trans-Carveol OM & 0.6 & 1700 & 1695 & Germacra-4(15),5,10(14)-trien- $1 \beta$-ol OS & 1.7 \\
\hline 1227 & 1230 & cis-p-Mentha-1(7),8-dien-2-ol OM & 0.2 & 1765 & 1767 & $\beta-$ Costol ÓS & 1.3 \\
\hline 1229 & 1235 & (3Z)-Hexenyl 3-methylbutanoate ${ }^{\mathrm{E}}$ & 0.2 & 1854 & 1847 & Phytone OC & 0.4 \\
\hline 1234 & 1236 & n-Hexyl 2-methylbutanoate ${ }^{\mathrm{E}}$ & 0.1 & 1984 & 1960 & Palmitic acid OC & 1.2 \\
\hline 1240 & 1241 & Cuminaldehyde $\mathrm{OM}$ & 0.2 & 2087 & 2106 & Phytol DT & 0.3 \\
\hline 1244 & 1243 & Carvone $\mathrm{OM}$ & 0.1 & & & Total identified & 93.0 \\
\hline
\end{tabular}

RIcalc $=$ retention index determined with respect to a homologous series of $n$-alkanes on a HP- $5 \mathrm{~ms}$ column; RIdb $=$ retention index from the databases $[19,20] ; \mathrm{MH}=$ monoterpene hydrocarbone; $\mathrm{OM}=$ oxygenated monoterpene; $\mathrm{SH}=$ sesquiterpene hydrocarbone; $\mathrm{OS}=$ oxygenated sesquiterpene; $\mathrm{DT}=$ diterpene; $\mathrm{PP}=$ phenylpropene; $\mathrm{E}=$ ester; $\mathrm{OC}=$ other components. 


\subsection{Insecticidal Activity}

Based on oral and fumigant bioassays, A. annua essential oil was toxic to 4th instar larva of $G$. pyloalis $24 \mathrm{~h}$ post treatments. Probit analysis revealed that the $\mathrm{LC}_{50}$ values were $1.204 \% \mathrm{~W} / \mathrm{V}$ and $3.343 \mu \mathrm{L} / \mathrm{L}$ air for oral and fumigant toxicity, respectively. The mortality of tested larvae was augmented with increasing concentration (Table 2). Besides $\mathrm{LC}_{50}$, the $\mathrm{LC}_{10}$ and $\mathrm{LC}_{30}$ values were used to evaluate sublethal bio-activities, including effects on energy reserves, digestive and detoxifying enzymes activity, and hematological and immunity responses and histological study of midgut and ovary of larvae (Table 2).

Table 2. Probit analysis of the oral and fumigant toxicity of Artemisia annua floral essential oil on 4th instar larva of Glyphodes pyloalis.

\begin{tabular}{|c|c|c|c|c|c|c|}
\hline Bioassay & $\begin{array}{c}\mathrm{LC}_{10} \\
(95 \% \mathrm{CL})\end{array}$ & $\begin{array}{c}\mathrm{LC}_{30} \\
(95 \% \mathrm{CL})\end{array}$ & $\begin{array}{c}\mathrm{LC}_{50} \\
(95 \% \mathrm{CL})\end{array}$ & $\begin{array}{c}\mathrm{LC}_{90} \\
(95 \% \mathrm{CL})\end{array}$ & Slope \pm SE & $\begin{array}{c}X^{2} \\
(\mathrm{df}=3)\end{array}$ \\
\hline Oral toxicity & $\begin{array}{c}0.593 \\
(0.395-0.735)\end{array}$ & $\begin{array}{c}0.901 \\
(0.725-1.058)\end{array}$ & $\begin{array}{c}1.204 \\
(1.024-1.466)\end{array}$ & $\begin{array}{c}2.445 \\
(1.882-4.128)\end{array}$ & $4.165 \pm 0.631$ & 3.2567 \\
\hline $\begin{array}{l}\text { Fumigant } \\
\text { toxicity }\end{array}$ & $\begin{array}{c}1.945 \\
(1.568-2.240)\end{array}$ & $\begin{array}{c}2.678 \\
(2.347-2.948)\end{array}$ & $\begin{array}{c}3.343 \\
(3.048-3.632)\end{array}$ & $\begin{array}{c}5.745 \\
(5.112-6.825)\end{array}$ & $5.449 \pm 0.788$ & 2.976 \\
\hline
\end{tabular}

LC: lethal concentration (\% W/V for oral toxicity and $\mu \mathrm{L} / \mathrm{L}$ for fumigant toxicity), CL: confidence limits, $\mathrm{X}^{2}$ : Chi-square value, and df: degrees of freedom. According to Chi-square values, no heterogeneity factor was used in the calculation of confidence limits. Concentration rates were $0.5-2 \%(\mathrm{~W} / \mathrm{V})$ and $2-6 \mu \mathrm{L} / \mathrm{L}$ air for oral and fumigant toxicity, respectively.

\subsection{Energy Reserves}

The essential oil of A. annua flowers on the energy reserves of G. pyloalis larvae is shown in Table 3. As can be seen, for all macromolecules, increasing dose of essential oil decreased the concentrations of protein, glucose, and triglycerides. For example, doubling the essential oil concentration $\left(\mathrm{LC}_{10}\right.$ to $\mathrm{LC}_{50}$ ) reduced glucose by $29 \%$ in oral tests, while a 1.7 -fold increase in fumigant concentration resulted in a $32 \%$ drop in glucose levels. The protein was also affected but the decrease in protein with increasing essential oil levels was insufficient to detect given background variability.

Table 3. Effect of Artemisia annua flowers' essential oil on macromolecules in 4th instar larvae of Glyphodes pyloalis.

\begin{tabular}{|c|c|c|c|c|}
\hline Bio-assay & Concentrations & Protein $(\mathrm{mg} / \mathrm{dL})$ & Glucose (mg/dL) & Triglyceride (mg/dL) \\
\hline \multirow{6}{*}{ Oral toxicity $(\% \mathrm{~W} / \mathrm{V})$} & Control & $1.0200 \pm 0.0360^{\mathrm{a}}$ & $1.7733 \pm 0.0247^{\mathrm{a}}$ & $1.8800 \pm 0.0145^{\mathrm{a}}$ \\
\hline & $\mathrm{LC}_{10}$ & $0.9833 \pm 0.0088^{\mathrm{a}}$ & $1.6666 \pm 0.0033^{\mathrm{a}}$ & $1.8033 \pm 0.0617^{\mathrm{a}}$ \\
\hline & $\mathrm{LC}_{30}$ & $0.9700 \pm 0.0057^{\mathrm{a}}$ & $1.6533 \pm 0.0290^{\mathrm{a}}$ & $1.6557 \pm 0.0531^{\mathrm{a}}$ \\
\hline & $\mathrm{LC}_{50}$ & $0.9533 \pm 0.0088^{a}$ & $1.1733 \pm 0.0783^{b}$ & $1.1700 \pm 0.0577^{b}$ \\
\hline & F-Value & 2.16 & 29.51 & 19.65 \\
\hline & $\operatorname{Pr}$ & 0.0170 & 0.0001 & 0.0005 \\
\hline \multirow{6}{*}{$\begin{array}{l}\text { Fumigant toxicity } \\
\qquad(\mu \mathrm{L} / \mathrm{L})\end{array}$} & Control & $1.0400 \pm 0.0208^{a}$ & $1.8100 \pm 0.0655^{\mathrm{a}}$ & $1.9200 \pm 0.0964^{\mathrm{a}}$ \\
\hline & $\mathrm{LC}_{10}$ & $0.9900 \pm 0.0057^{\mathrm{ab}}$ & $1.7266 \pm 0.0384^{\mathrm{a}}$ & $1.7533 \pm 0.0635^{\mathrm{ab}}$ \\
\hline & $\mathrm{LC}_{30}$ & $0.9700 \pm 0.0032^{b}$ & $1.6900 \pm 0.0208^{a}$ & $1.433 \pm 0.2185^{\mathrm{ab}}$ \\
\hline & $\mathrm{LC}_{50}$ & $0.9366 \pm 0.0088^{b}$ & $1.1633 \pm 0.0317^{b}$ & $1.3000 \pm 0.0765^{b}$ \\
\hline & F-Value & 12.94 & 47.80 & 5.04 \\
\hline & $\operatorname{Pr}$ & 0.0019 & 0.0001 & 0.0300 \\
\hline
\end{tabular}

In each separate column, means followed by different letters designate significant differences at $p<0.05$ according to Tukey's test.

\subsection{Digestive and Detoxifying Enzymes}

The effects of $A$. annua floral essential oil on digestive enzymes' activity of G. pyloalis larvae was manifested by a decrease in protease, $\alpha$-glucosidase, $\beta$-glucosidase, $\alpha$-amylase, and lipase contents. The difference was significant between the $\mathrm{LC}_{50}$ versus the control in both oral and fumigant applications while other concentrations of the essential oil produced intermediate responses (Table 4). 
The effect of essential oil of $A$. annua flowers on the activity of esterase and glutathione S-transferase (GST) of G. pyloalis larvae is shown in the Table 5. Glutathione S-transferase and esterase contents were reduced significantly when $\mathrm{LC}_{50}$ was applied in both oral and fumigation methods compared to the controls (Table 5).

\subsection{Hematological Study and Immunity Responses}

The essential oil affected the immune system, which included cellular quantity and quality, phenol oxidase activity, and the immune responses after B. bassiana and latex beads' injection (Figures 1-4). Total hemocyte counts (THC), plasmatocytes and granular cells, nodule formation, and phenol oxidase activity was recorded the lowest in $\mathrm{LC}_{50}$ both in oral and fumigation assays, respectively.
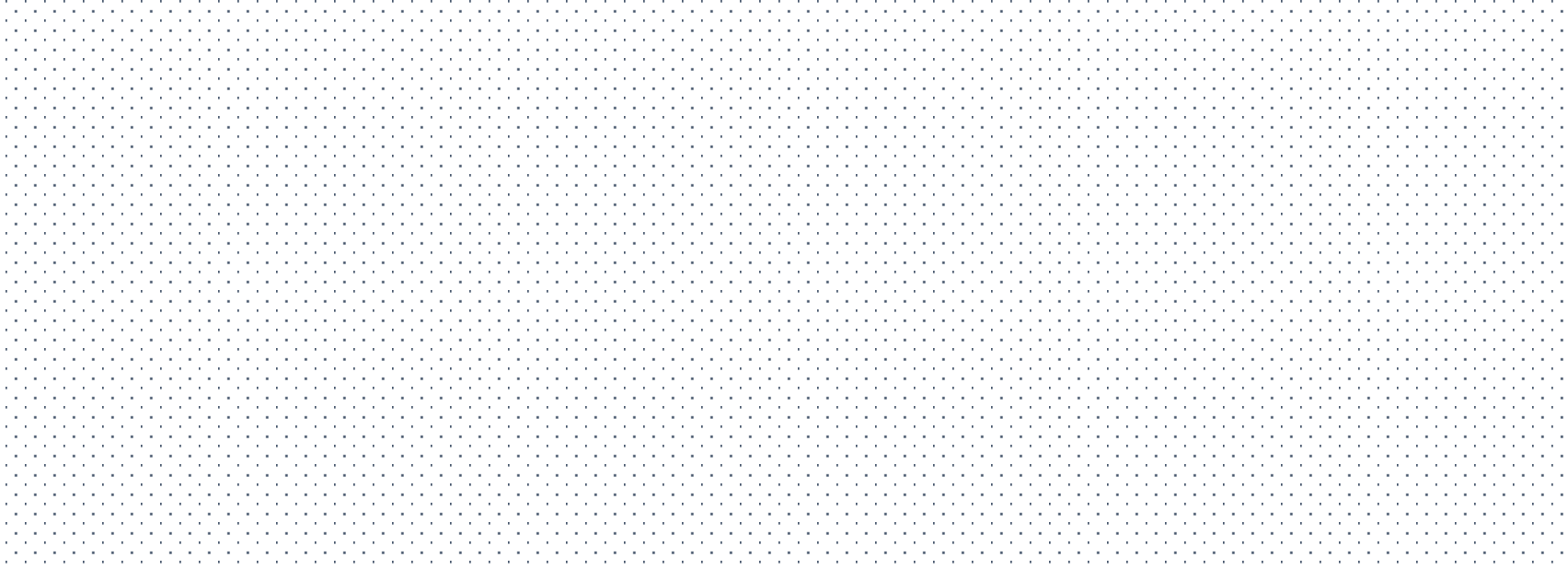

Figure 1. The effect of Artemisia annua floral essential oil on total hemocyte counts (THC) of Glyphodes pyloalis larvae treated with oral (A) and fumigant (B) assays. Bars with different letters above them indicate significant differences between means at $p<0.05$, Tukey's test. Number of hemocytes $\times 10^{4}$.
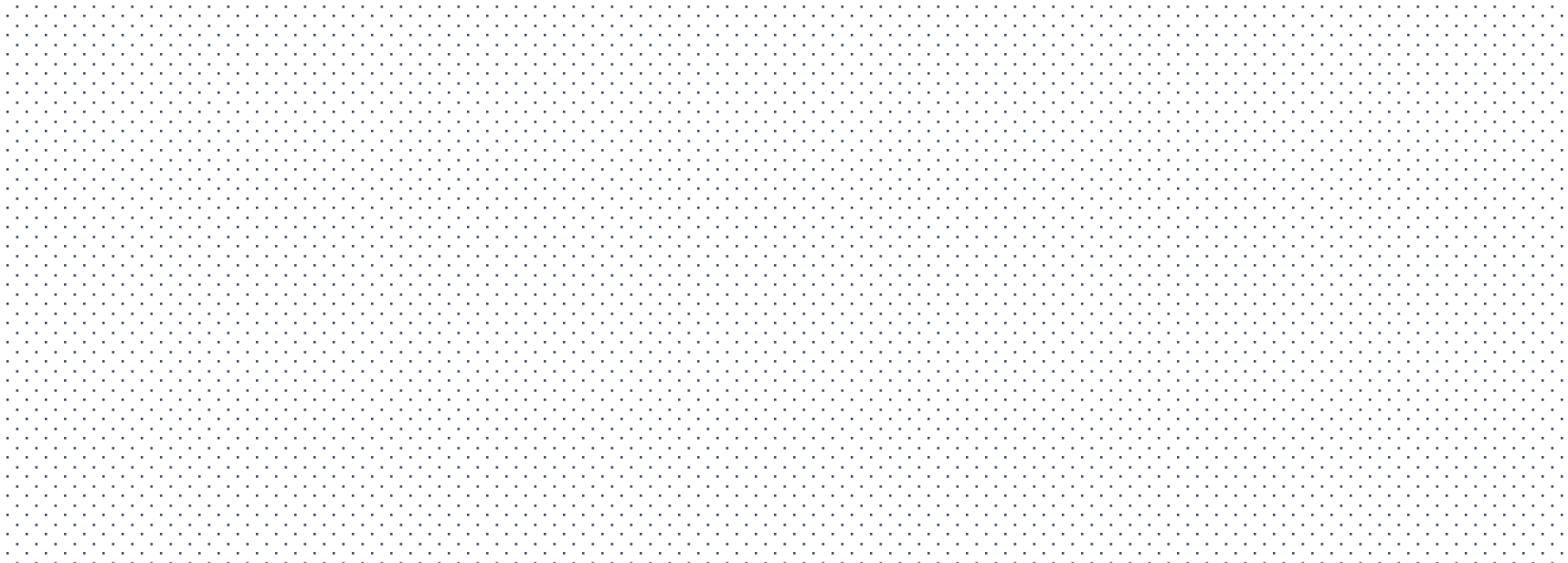

Figure 2. The effect of Artemisia annua floral essential oil on the plasmatocytes and granular cells of Glyphodes pyloalis larvae treated with oral (A) and fumigant (B) assays. Bars with different letters indicate significant differences among means of each hemocyte at $p<0.05$, Tukey's test. The number of hemocytes $\times 10^{4}$. 
Table 4. Effect of Artemisia annua floral essential oil on digestive enzyme activities in 4th instar larvae of Glyphodes pyloalis.

\begin{tabular}{|c|c|c|c|c|c|c|c|}
\hline Bio-assay & $\begin{array}{l}\text { Digestive Enzymes } \\
\text { (U/mg Protein) }\end{array}$ & Control & $\mathrm{LC}_{10}$ & $\mathrm{LC}_{30}$ & $\mathrm{LC}_{50}$ & F-Value & Pr \\
\hline \multirow{5}{*}{$\begin{array}{l}\text { Oral toxicity } \\
(\% \mathrm{~W} / \mathrm{V})\end{array}$} & Protease & $1.9467 \pm 0.3525^{\mathrm{a}}$ & $1.7833 \pm 0.1201^{\mathrm{ab}}$ & $1.5433 \pm 0.0876^{\mathrm{ab}}$ & $1.0667 \pm 0.0437^{b}$ & 3.96 & 0.0531 \\
\hline & $\alpha$-glucosidase & $1.374 \pm 0.192^{\mathrm{a}}$ & $1.046 \pm 0.0825^{\mathrm{ab}}$ & $0.7119 \pm 0.0333^{b}$ & $0.5640 \pm 0.0360^{b}$ & 9.31 & 0.0055 \\
\hline & $\beta$-glucosidase & $1.4451 \pm 0.1165^{\mathrm{a}}$ & $1.1635 \pm 0.0955^{\mathrm{a}}$ & $0.8757 \pm 0.05365^{b}$ & $0.6873 \pm 0.0515^{b}$ & 15.61 & 0.0010 \\
\hline & $\alpha$-amylase & $0.3066 \pm 1.732^{a}$ & $0.2633 \pm 0.0202^{\mathrm{ab}}$ & $0.2333 \pm 0.01763^{b}$ & $0.0833 \pm 0.0120^{\mathrm{c}}$ & 41.32 & 0.0001 \\
\hline & Lipase & $0.0571 \pm 0.032^{a}$ & $0.0387 \pm 0.064^{\mathrm{ab}}$ & $0.03806 \pm 0.089^{b}$ & $0.03700 \pm 0.059^{b}$ & 22.75 & 0.0003 \\
\hline \multirow{5}{*}{$\begin{array}{l}\text { Fumigant toxicity } \\
\qquad(\mu \mathrm{L} / \mathrm{L})\end{array}$} & Protease & $1.8333 \pm 0.1244^{\mathrm{a}}$ & $0.8967 \pm 0.1197^{\mathrm{b}}$ & $0.7167 \pm 0.1591^{b}$ & $0.4067 \pm 0.1591^{b}$ & 15.83 & 0.0010 \\
\hline & $\alpha$-glucosidase & $1.2034 \pm 0.039^{a}$ & $1.1083 \pm 0.266^{\mathrm{a}}$ & $0.8870 \pm 0.064^{b}$ & $0.6921 \pm 0.038^{b}$ & 20.80 & 0.0004 \\
\hline & $\beta$-glucosidase & $1.3451 \pm 0.0330^{\mathrm{a}}$ & $1.3183 \pm 0.1830^{a}$ & $0.9537 \pm 0.0282^{a b}$ & $0.7591 \pm 0.0717^{b}$ & 8.07 & 0.0084 \\
\hline & $\alpha$-amylase & $0.2800 \pm 0.0057^{a}$ & $0.2700 \pm 0.01731^{\mathrm{ab}}$ & $0.2300 \pm 0.11541^{\mathrm{ab}}$ & $0.1333 \pm 0.0145^{b}$ & 37.49 & 0.0001 \\
\hline & Lipase & $0.0559 \pm 0.0010^{a}$ & $0.0436 \pm 0.0012^{b}$ & $0.0378 \pm 0.0027^{b}$ & $0.02620 \pm 0.0025^{c}$ & 37.68 & 0.0001 \\
\hline
\end{tabular}

In each separate row, means followed by different letters designate significant differences at $p<0.05$ according to Tukey's test. 
Table 5. Effect of the different concentrations of Artemisia annua flowers' essential oil on the activity of glutathione S-transferase (GST) and esterase in 4th instar larvae of Glyphodes pyloalis.

\begin{tabular}{|c|c|c|c|}
\hline Bio-assay & Concentrations & GST (U/mg Protein) & $\begin{array}{l}\text { Esterase }(\mathrm{U} / \mathrm{mg} \\
\text { Protein) }\end{array}$ \\
\hline \multirow{6}{*}{$\begin{array}{l}\text { Oral toxicity } \\
(\% \mathrm{~W} / \mathrm{V})\end{array}$} & Control & $0.02300 \pm 0.001^{\mathrm{a}}$ & $0.0953 \pm 0.004^{\mathrm{a}}$ \\
\hline & $\mathrm{LC}_{10}$ & $0.01733 \pm 0.0032^{\mathrm{a}}$ & $0.08266 \pm 0.007^{\mathrm{ab}}$ \\
\hline & $\mathrm{LC}_{30}$ & $0.0065 \pm 0.0025^{b}$ & $0.07366 \pm 0.002^{\mathrm{ab}}$ \\
\hline & $\mathrm{LC}_{50}$ & $0.0001 \pm 0.00001^{b}$ & $0.06700 \pm 0.001^{\mathrm{b}}$ \\
\hline & F-Value & 23.46 & 14.13 \\
\hline & $\operatorname{Pr}$ & 0.0003 & 0.0483 \\
\hline \multirow{6}{*}{$\begin{array}{l}\text { Fumigant toxicity } \\
\qquad(\mu \mathrm{L} / \mathrm{L})\end{array}$} & Control & $0.02266 \pm 0.0008^{a}$ & $0.09566 \pm 0.004^{\mathrm{a}}$ \\
\hline & $\mathrm{LC}_{10}$ & $0.01533 \pm 0.0006^{\mathrm{a}}$ & $0.07966 \pm 0.0005^{\mathrm{ab}}$ \\
\hline & $\mathrm{LC}_{30}$ & $0.0010 \pm 0.0001^{b}$ & $0.06066 \pm 0.0063 \mathrm{ab}$ \\
\hline & $\mathrm{LC}_{50}$ & $0.0001 \pm 0.0000^{b}$ & $0.04600 \pm 0.0024^{b}$ \\
\hline & F-Value & 30.13 & 22.27 \\
\hline & $\operatorname{Pr}$ & 0.0001 & 0.0003 \\
\hline
\end{tabular}

In each separate column, means followed by different letters indicate significant differences at $p<0.05$ according to Tukey's test.
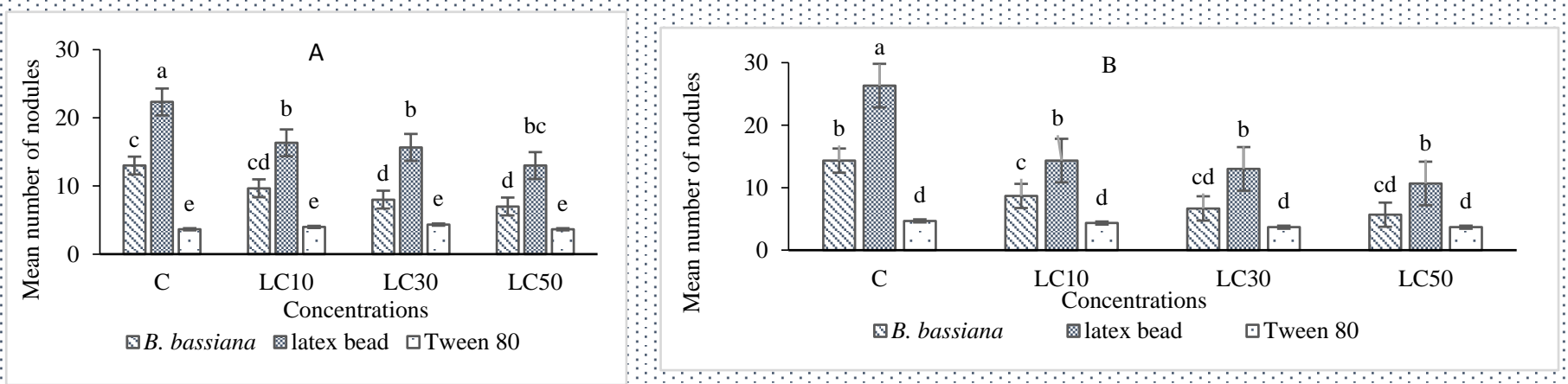

Figure 3. Effects of Artemisia annua floral essential oil on the nodule formation of Glyphodes pyloalis larvae treated with oral (A) and fumigant assays (B) and inoculated with Beauveria bassiana spores or latex beads. Bars with different letters indicate significant differences between means at $p<0.05$. Tukey's test. The number of hemocytes $\times 10^{4}$.
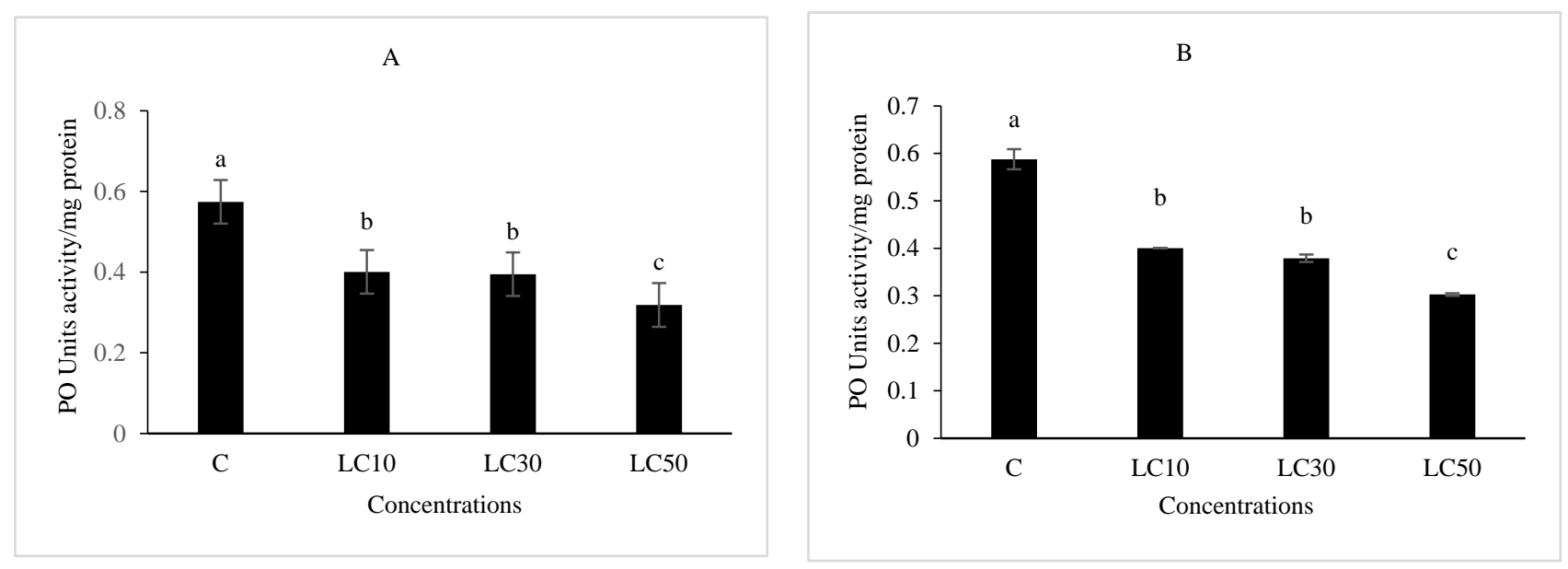

Figure 4. The effect of Artemisia annua floral essential oil on phenol oxidase (PO) activity of Glyphodes pyloalis larvae treated with oral (A) and fumigant (B) assays. Bars with different letters above them indicate significant differences between means at $p<0.05$, Tukey's test. The number of hemocytes $\times 10^{4}$. 


\subsection{Histological Studies}

The histological texture of larval midgut upon treatment with $A$. annua essential oil revealed significant differences with the controls, the most significant of which was the elongation and separation of epithelial cells losing the compactness (Figure 5). The most significant changes in ovarian structure was thinning of epithelial cells around each follicle compared with that of control. Also, the significant reduction in cytoplasm was seen after vacuolization in yolk spheres of the oocytes (Figure 6).
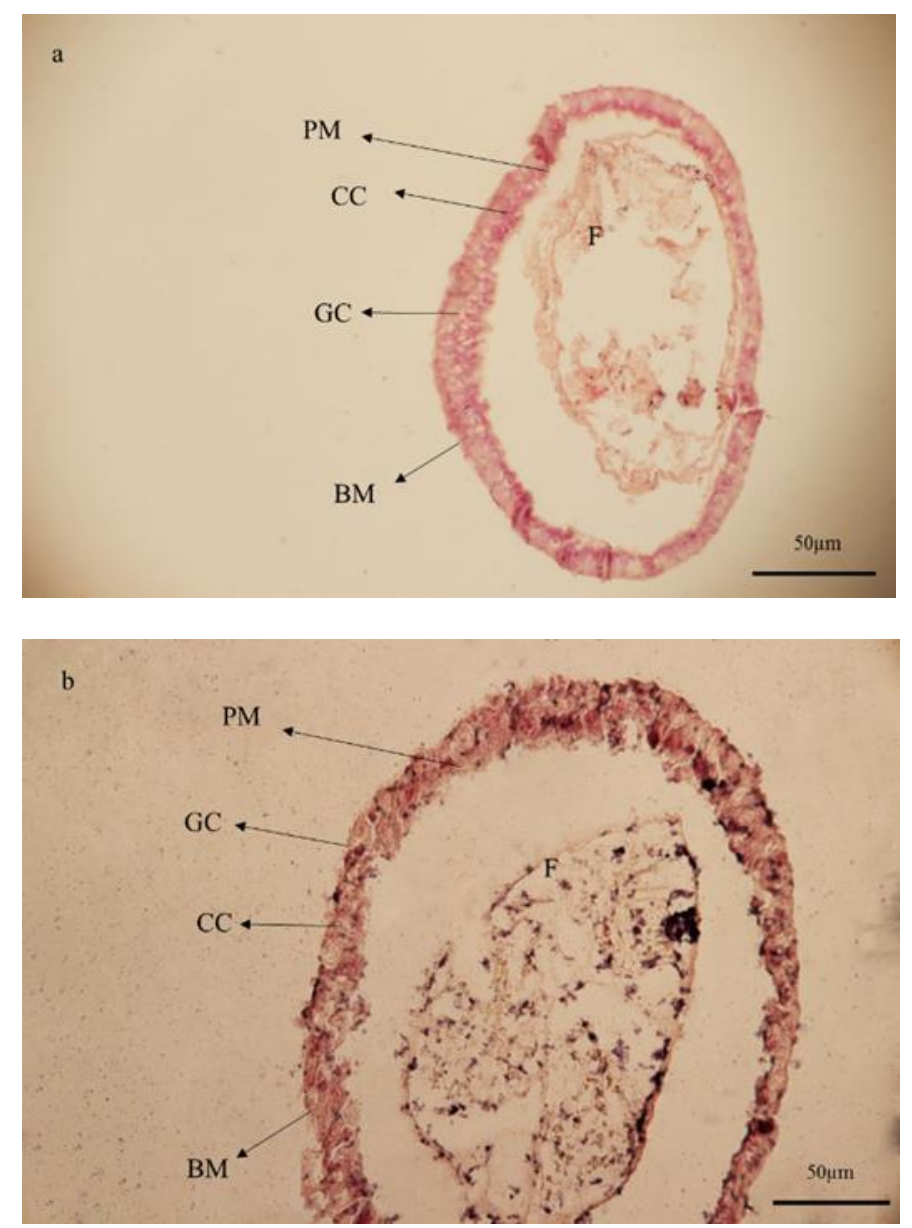

Figure 5. Light microscopy of the larval midgut of Glyphodes pyloalis in control (a) and after oral treatment with Artemisia annua floral essential oil (b). Normal texture of all cell types (a) was contrasted to changes in size and texture in treated larvae (b). In the midgut of insects treated with essential oil from A. annua the cohesion of the columnar epithelial layer was damaged. (BM) basement membrane, (CC) columnar cell, (GC) goblet cell, and (PM) peritrophic membrane. 

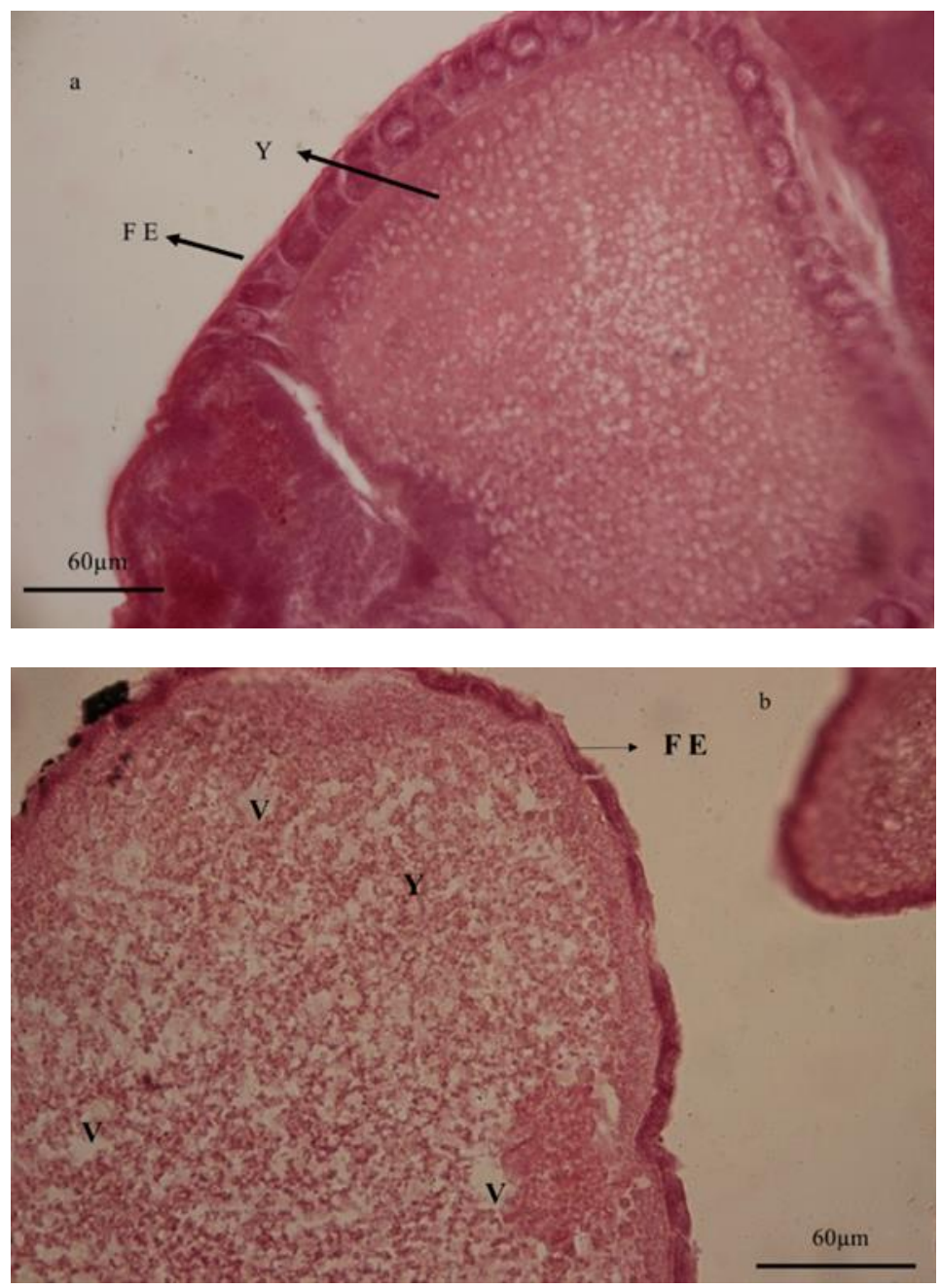

Figure 6. Histology of ovaries in adults of Glyphodes pyloalis emerging from untreated (a) and treated larvae by Artemisia annua floral essential oil (b). In treatments of the ovarian sheath significant changes and yolk granules were reduced under the influence of vacuolization in cytoplasm compared to the control. (FE) follicular epithelium, (V) vacuole, and (Y) yolk granules.

\section{Discussion}

The chemical composition of $A$. аппиа essential oil in the vegetative stage was investigated in the previous studies [15,36-39], in which terpenes such as 1,8-cineole, camphor, and artemisia ketone were introduced as major constituents. Although 1,8-cineole (6.8\%), camphor $(13.1 \%)$, and artemisia ketone $(11.8 \%)$ were also identified as main compounds in the essential oil extracted from $A$. annua flowers, some other terpenes such as $\beta$-selinene $(10.7 \%)$, pinocarvone $(7.4 \%)$, and $\alpha$-pinene $(5.9 \%)$ had high amounts. However, a range of minor constituents, including compounds from ester and phenylpropene groups, were also recognized. Such differences can be caused by exogenous and endogenous factors, including geographic location, harvesting time, and the growth stage of plants [40]. The chemical composition of each essential oil has a significant impact on its insecticidal activity. For example, the promising insecticidal effects of terpenes like camphor and 1,8-cineole identified and extracted from essential oils were reported [41,42].

Our study clearly showed decreased enzymatic activity in G. pyloalis larvae related to ingestion of $A$. annua essential oil-treated mulberry leaves. Our findings support earlier findings where disruption in insects' physiology and their inability to digest food was reported [43,44]. Reduction in $\alpha$-amylase, protease, and $\alpha$ - and $\beta$-glucosidase, and disruptions on immunology and digestive system in the larvae and the ovary of emerged adults of G. pyloalis were described in our results. Such activities are common for botanical 
insecticides against several insect pests [45-47]. Also, there were further supports for the interference or even deformation of midgut cells, which were responsible for the production of key enzymes in insects [15,48].

Protein plays a key role in digestion, metabolism, and also energy conversion. Klowden (2007) [49] believes that reduction in the insect's protein content after applying biopesticides may stem from the reduction of growth hormone level. We observed a reduction in protein content and also retardation in growth; however, growth hormone level was not worked out. Lipids are other important macromolecules that help the insect reserve energy from feeding. They play a key role in insects' intermediary metabolism and, therefore, they are essential in insect physiology [49]. Significant reduction in the triglyceride content of G. pyloalis larvae treated with $A$. annua essential oil was observed in the present study. There are several reasons for reducing insect lipid content after treatments by toxins, alteration in lipid synthesis patterns, and hormonal dysfunction to control its metabolism [49]. Glucose as a key carbohydrate (monosaccharide) was also decreased following treatment with $A$. annua essential oil. This reduction could be related to reduced feeding following treatment, since the essential oil acts as a deterrent [2]. Any disruption causing reducing resources at larval stages could affect insects' survival and reproduction in their later generations. A reduction in protein, lipid, and glucose contents may have adverse effects on the reproductive parameters such as egg production, fertility, and fecundity [50].

Detoxifying enzymes, including esterases and glutathione $S$-transferases, are involved in reducing the impacts of exogenous compounds [51]. In the current study, the activity of detoxifying enzymes, including esterases and glutathione $S$-transferases, was reduced by essential oil of $A$. аnnua flowers. Certainly, the reduced activity of these enzymes is related to their production halt somewhere in the process of production [15].

Insect cellular immunity is considered as the main system challenging natural enemies entering the insect body [52]. The immunocytes provide the insect ability to combat invading organisms by several means including phagocytosis, nodulation, and encapsulation [53]. So, the reduced immunocytes, as shown for G. pyloalis larvae treated with $A$. annua essential oil in the present study, could cause larvae to become susceptible to any invasion [54,55]. The reduced number of hemocytes is mostly due to cytotoxic effect of the botanicals used [56]. We do believe this toxic effect of botanicals to be more reliable as a reasoning for the reduction of immunocytes [57-59].

Phenol oxidase system is considered as the key component in the immune system of insect and a bridge in the gap between cellular and humeral insect immunity. Its action is critically required in the last stage of cellular defense in order to form melanization, a process that terminates the action and kills the pathogenic agent. Phenol oxidase inhibition, documented for G. pyloalis larvae treated with A. annua essential oil in the present study, probably helps to make the insects susceptible to pathogenic agents if they have not received the toxic concentration $[45,58,60]$.

The insect midgut principal cells are the main cells taking the role of producing the enzymes needed for digestion and then absorbing the nutrients. Therefore, any damages to these cells will lower the activities in digestive enzymes already reported by other researchers $[15,31,61]$. The elongation and separation of midgut epithelial cells of G. pyloalis larvae treated by $A$. апnиa essential oil were observed in the present study.

Inhibiting insect reproduction has long been the subject of many studies. In lepidopterans, obtaining all nutrients at larval stages is necessary for reproductive development [62]. So, if larval nutrition is disrupted by any means, it will be reflected in adult reproductive function. Our previous findings and the current study display the changes in morphology and histology of emerging adults [15,31]. Our study showed the essential oil of A. annua brought about subtle changes in ovarian tissue, such as disruption of follicular cells. As the insect tries to compromise to reduce nutrients in detoxification processes, follicles' cells deplete its content into the oocytes, which then disrupts the cell texture [63]. 


\section{Conclusions}

Plant-derived allelochemicals are beneficial agents in controlling pests. As we know, the plant kingdom mainly depends on secondary metabolites to defend against herbivores. With this knowledge in mind, scientists exploit the use of secondary plant chemicals for pest control. One of the main reasons for this increased demand is that the plant-originated chemicals are comparatively safer for humans and the environment. Our study's results clearly document that the essential oil of $A$. annua flowers is toxic to larval mulberry pyralid and disrupt its various physiological systems in a way that the insect can hardly get resistance to it. Consequently, this wild-growing plant in Iran can be considered an efficient natural source capable of controlling insect pests. To apply the research results, it is recommended to evaluate the possible side effects of essential oil on mulberry and the biological control agents in future research. Regarding the insect pest's resistance, identifying specific modes of action of essential oil active components and their overlapping with other insecticides should also be assessed.

Author Contributions: Conceptualization, M.O., J.J.S., and A.E.; methodology, M.O. and J.J.S.; formal analysis, M.O., J.J.S., A.E., and W.N.S.; investigation, M.O.; writing-original draft preparation, M.O., J.J.S., A.E. and P.K.; writing-review and editing, M.O., J.J.S., A.E., P.K. and W.N.S.; supervision, J.J.S. and A.E.; funding acquisition, P.K. All authors have read and agreed to the published version of the manuscript.

Funding: This research received no external funding.

Institutional Review Board Statement: Not applicable.

Informed Consent Statement: Not applicable.

Data Availability Statement: The data that support the findings of this study are available upon request from the authors.

Acknowledgments: This research was financially supported by the University of Guilan, Rasht, Iran, and was partially supported by Chiang Mai University, Thailand, which is greatly appreciated. W.N.S. participated in this work as part of the activities of the Aromatic Plant Research Center (APRC, https:/ / aromaticplant.org/).

Conflicts of Interest: The authors declare no conflict of interest.

\section{References}

1. Khosravi, R.; Sendi, J.J. Biology and demography of Glyphodes pyloalis Walker (Lepidoptera: Pyralidae) on mulberry. J. Asia-Pacific Èntomol. 2010, 13, 273-276. [CrossRef]

2. Isman, M.B. Plant essential oils for pest and disease management. Crop. Prot. 2000, 19, 603-608. [CrossRef]

3. Lamichhane, J.R.; Dachbrodt-Saaydeh, S.; Kudsk, P.; Messéan, A. Toward a reduced reliance on conventional pesticides in european agriculture. Plant. Dis. 2016, 100, 10-24. [CrossRef] [PubMed]

4. El Asbahani, A.; Miladi, K.; Badri, W.; Sala, M.; Addi, E.H.A.; Casabianca, H.; El Mousadik, A.; Hartmann, D.; Jilale, A.; Renaud, F.N.R.; et al. Essential oils: From extraction to encapsulation. Int. J. Pharm. 2015, 483, 220-243. [CrossRef] [PubMed]

5. Isman, M.B.; Grieneisen, M.L. Botanical insecticide research: Many publications, limited useful data. Trends Plant. Sci. 2014, 19, 140-145. [CrossRef]

6. Ebadollahi, A.; Ziaee, M.; Palla, F. Essential oils extracted from different species of the Lamiaceae plant family as prospective bioagents against several detrimental pests. Molecules 2020, 25, 1556. [CrossRef]

7. Basaid, K.; Chebli, B.; Mayad, E.H.; Furze, J.N.; Bouharroud, R.; Krier, F.; Barakate, M.; Paulitz, T. Biological activities of essential oils and lipopeptides applied to control plant pests and diseases: A review. Int. J. Pest. Manag. 2020, 1-23. [CrossRef]

8. Campos, E.V.; Proença, P.L.; Oliveira, J.L.; Bakshi, M.; Abhilash, P.; Fraceto, L.F. Use of botanical insecticides for sustainable agriculture: Future perspectives. Ecol. Indic. 2019, 105, 483-495. [CrossRef]

9. Nathan, S.S.; Choi, M.-Y.; Paik, C.-H.; Seo, H.-Y. Food consumption, utilization, and detoxification enzyme activity of the rice leaffolder larvae after treatment with Dysoxylum triterpenes. Pestic. Biochem. Physiol. 2007, 88, 260-267. [CrossRef]

10. Lazarevic, J.; Jevremović, S.; Kostić, I.; Kostić, M.; Vuleta, A.; Jovanović, S.M.; Jovanović, D. Šešlija Toxic, oviposition deterrent and oxidative stress effects of Thymus vulgaris essential oil against Acanthoscelides obtectus. Insects 2020, 11, 563. [CrossRef]

11. Afraze, Z.; Sendi, J.J.; Karimi-Malati, A.; Zibaee, A. Methanolic extract of winter cherry causes morpho-histological and immunological ailments in mulberry pyralid Glyphodes pyloalis. Front. Physiol. 2020, 11, 908. [CrossRef] [PubMed] 
12. Konovalov, D.; Khamilonov, A.A. Biologically active compounds of Artemisia annua essential oil. Pharm. Pharmacol. 2016,4 , 4-33. [CrossRef]

13. Xiao, L.; Tan, H.; Zhang, L. Artemisia annua glandular secretory trichomes: The biofactory of antimalarial agent artemisinin. Sci. Bull. 2016, 61, 26-36. [CrossRef]

14. Shekari, M.; Sendi, J.J.; Etebari, K.; Zibaee, A.; Shadparvar, A. Effects of Artemisia annua L. (Asteracea) on nutritional physiology and enzyme activities of elm leaf beetle, Xanthogaleruca luteola Mull. (Coleoptera: Chrysomellidae). Pestic. Biochem. Physiol. 2008, 91, 66-74. [CrossRef]

15. Hasheminia, S.M.; Sendi, J.J.; Jahromi, K.T.; Moharramipour, S. The effects of Artemisia annua L. and Achillea millefolium L. crude leaf extracts on the toxicity, development, feeding efficiency and chemical activities of small cabbage Pieris rapae L. (Lepidoptera: Pieridae). Pestic. Biochem. Physiol. 2011, 99, 244-249. [CrossRef]

16. Zibaee, A. Botanical Insecticides and Their Effects on Insect Biochemistry and Immunity. In Pesticides in the Modern World—Pests Control and Pesticides Exposure and Toxicity Assessment; IntechOpen: London, UK, 2011.

17. Mojarab-Mahboubkar, M.; Sendi, J.J.; Aliakbar, A. Effect of Artemisia annua L. essential oil on toxicity, enzyme activities, and energy reserves of cotton bollworm Helicoverpa armigera (Hübner) (Lepidoptera: Noctuidae). J. Plant. Prot. Res. 2015, 55, 371-377. [CrossRef]

18. Oftadeh, M.; Sendi, J.J.; Ebadollahi, A. Toxicity and deleterious effects of Artemisia annua essential oil extracts on mulberry pyralid (Glyphodes pyloalis). Pestic. Biochem. Physiol. 2020, 170, 104702. [CrossRef]

19. Adams, R.P. Identification of Essential Oil Components by Gas. Chromatography/Mass Spectrometry, 4th ed.; Allured Publishing Corporation: Carol Stream, IL, USA, 2007.

20. NIST. NIST17; National Institute of Standards and Technology: Gaithersburg, MD, USA, 2017.

21. Bernfeld, P. Amylases alpha and beta. Methods Enzymol. 1955, 1, 140-146.

22. García-Carreño, F.L.; Haard, N.F. Characterization of proteinase classes in Langostilla (Pleuroncodes planipes) and Crayfish (Pacifastacus astacus) extracts. J. Food Biochem. 1993, 17, 97-113. [CrossRef]

23. Tsujita, T.; Ninomiya, H.; Okuda, H. P-nitrophenyl 865. buyrate hydrolyzing activity of Hormone-senditive lipase 866 from bovine adipose tissue. J. Lipid. Res. 1989, 30, 867-997. [CrossRef]

24. Ferreira, C.; Terra, W.R. Physical and kinetic properties of a plasma-membrane-bound $\beta$-d-glucosidase (cellobiase) from midgut cells of an insect (Rhynchosciara americana larva). Biochem. J. 1983, 213, 43-51. [CrossRef] [PubMed]

25. Bradford, M.M. A rapid and sensitive method for the quantitation of microgram quantities of protein utilizing the principle of protein-Dye binding. Anal. Biochem. 1976, 72, 248-254. [CrossRef]

26. Siegert, K.J. Carbohydrate metabolism in Manduca sexta during late larval development. J. Insect Physiol. 1987, 33, 421-427. [CrossRef]

27. Van Asperen, K. A study of housefly esterases by means of a sensitive colorimetric method. J. Insect Physiol. 1962, 8, 401-416. [CrossRef]

28. Habing, W.H.; Pabst, M.J.; Jakoby, W.B. Glutathione S-transferases. The first step in mercapturic acid formation. J. Biol. Chem. 1974, 249, 7130-7139.

29. Parkinson, N.M.; Weaver, R.J. Noxious Components of Venom from the Pupa-Specific Parasitoid Pimpla hypochondriaca. J. Invertebr. Pathol. 1999, 73, 74-83. [CrossRef]

30. El-Aziz, N.M.A.; Awad, H.H. Changes in the haemocytes of Agrotis ipsilon larvae (Lepidoptera: Noctuidae) in relation to dimilin and Bacillus thuringiensis infections. Micron 2010, 41, 203-209. [CrossRef]

31. Jones, J.C. Current concepts concerning insect hemocytes. Am. Zoöl. 1962, 2, 209-246. [CrossRef]

32. Arnold, J.W.; Hinks, C.F. Haemopoiesis in Lepidoptera. I. The multiplication of circulating haemocytes. Can. J. Zool. 1976, 54, 1003-1012. [CrossRef]

33. Seyedtalebi, F.S.; Safavi, S.; Talaei-Hasanloui, A.R.; Bandani, A.R. Quantitative comparison for some immune responses among Eurygaster integriceps, Ephestia kuehniella and Zophobas morio against the entomopathogenic fungus Beuveria bassiana. Invert. Surviv. J. 2017, 14, 174-181. [CrossRef]

34. LeOra Software. Polo Plus, a User's Guide to Probit or Logit Analysis; LeOra Software: Berkeley, CA, USA, 2002.

35. SAS Institute. SAS/STAT User's Guide for Personal Computers; SAS Institute: Cary, NC, USA, 1997.

36. Mojarab-Mahboubkar, M.; Sendi, J.J. Chemical composition, insecticidal and physiological effect of methanol extract of sweet wormwood (Artemisia annua L.) on Helicoverpa armigera (Hübner) (Lepidoptera: Noctuidae). Toxin Rev. 2016, 35, 106-115. [CrossRef]

37. Bedini, S.; Flamini, G.; Cosci, F.; Ascrizzi, R.; Echeverria, M.C.; Guidi, L.; Landi, M.; Benelli, G.; Conti, B. Artemisia spp. essential oils against the disease-carrying blowfly Calliphora vomitoria. Parasit. Vectors 2017, 10, 1-10. [CrossRef] [PubMed]

38. Pandey, A.K.; Singh, P. The Genus Artemisia: A 2012-2017 Literature review on chemical composition, antimicrobial, insecticidal and antioxidant activities of essential oils. Medicines 2017, 4, 68. [CrossRef]

39. Nigam, M.; Atanassova, M.; Mishra, A.P.; Pezzani, R.; Devkota, H.P.; Plygun, S.; Salehi, B.; Setzer, W.N.; Sharifi-Rad, J. Bio-active compounds and health benefits of Artemisia species. Nat Prod. Commun 2019. [CrossRef]

40. Isman, M.B. Commercial development of plant essential oils and their constituents as active ingredients in bioinsecticides. Phytochem. Rev. 2020, 19, 235-241. [CrossRef] 
41. Kumar, P.; Mishra, S.; Malik, A.; Satya, S. Repellent, larvicidal and pupicidal properties of essential oils and their formulations against the housefly, Musca domestica. Med. Veter Ėntomol. 2011, 25, 302-310. [CrossRef] [PubMed]

42. Filomeno, C.A.; Barbosa, L.C.; Teixeira, R.R.; Pinheiro, A.L.; Farias, E.D.S.; Ferreira, J.S.; Picanço, M.C. Chemical diversity of essential oils of Myrtaceae species and their insecticidal activity against Rhyzopertha dominica. Crop. Prot. 2020, 137, 105309. [CrossRef]

43. Shannag, H.K.; Capinera, J.L.; Freihat, N.M. Effects of neem-based insecticides on consumption and utilization of food in larvae of Spodoptera eridania (Lepidoptera: Noctuidae). J. Insect Sci. 2015, 15, 152. [CrossRef]

44. Zou, C.; Wang, Y.; Zou, H.; Ding, N.; Geng, N.; Cao, C.; Zhang, G. Sanguinarine in Chelidonium majus induced antifeeding and larval lethality by suppressing food intake and digestive enzymes in Lymantria dispar. Pestic. Biochem. Physiol. 2019, 153, 9-16. [CrossRef]

45. Zibaee, A.; Bandani, A.R. A study on the toxicity of the medicinal plant, Artemisia annua L. (Astracea) extracts the Sunn pest, Eurygaster integriceps Puton (Heteroptera: Scutelleridae). J. Plant. Prot. Res. 2010, 50, 48-54. [CrossRef]

46. Bezzar-Bendjazia, R.; Kilani-Morakchi, S.; Maroua, F.; Aribi, N. Azadirachtin induced larval avoidance and antifeeding by disruption of food intake and digestive enzymes in Drosophila melanogaster (Diptera: Drosophilidae). Pestic. Biochem. Physiol. 2017, 143, 135-140. [CrossRef] [PubMed]

47. Magierowicz, K.; Górska-Drabik, E.; Sempruch, C. The effect of Tanacetum vulgare essential oil and its main components on some ecological and physiological parameters of Acrobasis advenella (Zinck.) (Lepidoptera: Pyralidae). Pestic. Biochem. Physiol. 2020, 162, 105-112. [CrossRef] [PubMed]

48. Mishra, M.; Sharma, A.; Dagar, V.S.; Kumar, S. Effects of $\beta$-sitosterol on growth, development and midgut enzymes of Helicoverpa armigera Hübner. Arch. Biol. Sci. 2020, 72, 271-278. [CrossRef]

49. Klowden, M.J. Physiological Systems in Insects, 2nd ed.; Academic Press: Cambridge, MA, USA, 2007.

50. Wu, M.-Y.; Ying, Y.-Y.; Zhang, S.-S.; Li, X.-G.; Yan, W.-H.; Yao, Y.-C.; Shah, S.; Wu, G.; Yang, F.-L. Effects of diallyl trisulfide, an active substance from garlic essential oil, on energy metabolism in male moth Sitotroga cerealella (Olivier). Insects 2020, 11, 270. [CrossRef]

51. Nattudurai, G.; Baskar, K.; Paulraj, M.G.; Islam, V.I.H.; Ignacimuthu, S.; Duraipandiyan, V. Toxic effect of Atalantia monophylla essential oil on Callosobruchus maculatus and Sitophilus oryzae. Environ. Sci. Pollut. Res. 2016, 24, 1619-1629. [CrossRef]

52. Perazzolo, L.M.; Gargioni, R.; Ogliari, P.; Barracco, M.A. Evaluation of some hemato-immunological parameters in the shrimp Farfantepenaeus paulensis submitted to environmental and physiological stress. Aquac. 2002, 214, 19-33. [CrossRef]

53. Kraaijeveld, A.R.; Limentani, E.C.; Godfray, H.C.J. Basis of the trade-off between parasitoid resistance and larval competitive ability in Drosophila melanogaster. In Proceedings of the Royal Society B: Biological Sciences; The Royal Society: London, UK, 2001; Volume 268, pp. 259-261.

54. Ghasemi, V.; Yazdi, A.K.; Tavallaie, F.Z.; Sendi, J.J. Effect of essential oils from Callistemon viminalis and Ferula gummosaon toxicity and on the hemocyte profile of Ephestia kuehniella (Lep.: Pyralidae). Arch. Phytopathol. Plant. Prot. 2014, 47, 268-278. [CrossRef]

55. Sadeghi, R.; Eshrati, M.R.; Mortazavian, S.M.M.; Jamshidnia, A. The Effects of the essential oils isolated from four ecotypes of cumin (Cuminum cyminum L.) on the blood cells of the pink stem borer, Sesamia cretica Ledere (Lepidoptera: Noctuidae). J. Kans. Èntomol. Soc. 2019, 92, 390-399. [CrossRef]

56. Clark, K.D.; Strand, M.R. Hemolymph melanization in the silkmoth bombyx mori involves formation of a high molecular mass complex that metabolizes tyrosine. J. Biol. Chem. 2013, 288, 14476-14487. [CrossRef]

57. Khanikor, B.; Bora, D. Effect of plant based essential oil on immune response of silkworm, Antheraea assama Westwood (Lepidoptera: Saturniidae). Int. J. Ind. Ėntomol. 2012, 25, 139-146. [CrossRef]

58. Ghoneim, K. Disturbed hematological and immunological parameters of insects by botanicals as an effective approach of pest control: A review of recent progress. South Asian. J. Exp. Biol. 2018, 1, 112-144.

59. Rahimi, V.; Hajizadeh, J.; Zibaee, A.; Sendi, J.J. Changes in immune responses of Helicoverpa armigera Hübner followed by feeding on Knotgrass, Polygonum persicaria agglutinin. Arch. Insect Biochem. Physiol. 2019, 101, e21543. [CrossRef] [PubMed]

60. Cerenius, L.; Lee, B.L.; Söderhäll, K. The proPO-system: Pros and cons for its role in invertebrate immunity. Trends Immunol. 2008, 29, 263-271. [CrossRef] [PubMed]

61. Murfadunnisa, S.; Vasantha-Srinivasan, P.; Ganesan, R.; Senthil-Nathan, S.; Kim, T.-J.; Ponsankar, A.; Kumar, S.D.; Chandramohan, D.; Krutmuang, P. Larvicidal and enzyme inhibition of essential oil from Spheranthus amaranthroids (Burm.) against lepidopteran pest Spodoptera litura (Fab.) and their impact on non-target earthworms. Biocatal. Agric. Biotechnol. 2019, 21. [CrossRef]

62. Riddiford, L.M. How does juvenile hormone control insect metamorphosis and reproduction? Gen. Comp. Endocrinol. 2012, 179, 477-484. [CrossRef]

63. Reis, T.C.; Soares, M.A.; Dos Santos, J.B.; Dos Santos, C.A.; Serrão, J.E.; Zanuncio, J.C.; Ferreira, E.A. Atrazine and nicosulfuron affect the reproductive fitness of the predator Podisus nigrispinus (Hemiptera: Pentatomidae). Anais da Academia Brasileira de Ciências 2018, 90, 3625-3633. [CrossRef] 